IJCCS (Indonesian Journal of Computing and Cybernetics Systems)

Vol.14, No.1, January 2020, pp. 57 68

ISSN (print): 1978-1520, ISSN (online): 2460-7258

DOI: https://doi.org/10.22146/ijccs.51157

\title{
An Interactive Content Media on Information System iLearning+
}

\author{
Untung Rahardja ${ }^{1}$, Indri Handayani ${ }^{2}$, Ninda Lutfiani ${ }^{3}$, Fitra Putri Oganda ${ }^{* 4}$ \\ ${ }^{1,2,3,4}$ System Information Department, Faculty of Science and Technology, \\ Universitas Raharja, Tangerang, Indonesia \\ e-mail: : ${ }^{1}$ untung@ raharja.info , ${ }^{2}$ indri@ raharja.info, ${ }^{3}$ ninda@ raharja.info , \\ *4titra.putri@ raharja.info
}

\begin{abstract}
Abstrak
Seiring dengan meningkatnya perkembangan Teknologi Informasi dan Komunikasi (TIK), telah terjadi perubahan dalam metode pendekatan pembelajaran. Metode pembelajaran tatap muka (konvensional) dan ruang kelas sebagai implementasinya kini telah berubah. Sekarang metode pendekatan pembelajaran telah berubah menjadi arah pembelajaran di masa depan atau sebagai zaman pembelajaran pengetahuan. Dalam dunia pendidikan, informasi menjadi kebutuhan vital untuk mendukung kegiatan belajar mengajar. Dalam sistem pembelajaran online yang diterapkan untuk kebutuhan informasi iLearning + menjadi kebutuhan yang sangat penting di dalamnya. Namun dalam kenyataannya penyampaian informasi tidak dilakukan secara online tetapi dengan informasi konvensional seperti penyampaian informasi yang dilakukan di perantara antara dosen dan mahasiswa yang harus dilakukan tatap muka sehingga mendapat informasi. Maka dalam hal itu diperlukan suatu sistem untuk dapat menyampaikan informasi dengan sistem berbasis web sehingga pengiriman dapat dilakukan secara online dan dapat diakses kapan saja dan di mana saja tanpa dibatasi oleh waktu dan ruang. Dalam penelitian ini menggunakan metode penelitian tinjauan pustaka sebagai bahan pembanding pada penelitian yang ada.
\end{abstract}

Kata kunci-iLearning+, Sistem Informasi, Wordpress

\begin{abstract}
Along with the increasing development of Information and Communication Technology (ICT), there has been a change in the learning approach method. Methods of face-to-face learning (conventional) and classrooms as implementation have now changed. The ilearning method approach has turned into the direction of future learning or as a learning age of knowledge. In the world of education, information becomes a vital need to support teaching and learning activities. In the online learning system that applied to iLearning + information needs become critical needs therein. But in reality, the delivery of information is not done online, but with current information such as the delivery of information is done in an intermediary between lecturers and students, which must be done face to face so get a piece of information. So in that event, a system is needed to be able to convey information with a Web-based system so that delivery can be done online and can be accessed anytime and anywhere without being limited by time and space. In this study, using the literature review research method as a comparison material on existing research.
\end{abstract}

Keywords-iLearning+, Information Systems, Wordpress

Received November $4^{\text {th }}, 2019$; Revised December 13 ${ }^{\text {th }}, 2019$; Accepted December $27^{\text {th }}, 2020$ 


\section{INTRODUCTION}

In the era of industry 5.0, information is currently an essential requirement on the part of human life. The data that has obtained then processed into a report can be using the material for consideration for decision making and how information as decision making in solving a problem. Higher Education is a place to run education consisting of students as learners and lecturers as teaching staff to be able to achieve the national development goals[1]. The increasing development of information technology provides a presentation on a variety of information that can be accessed anytime and anywhere without any limitations on space or time with various devices. At this time, the internet is nothing new and foreign to our ears. Even the internet has now become a necessity because with the internet we can see the other side of the outside world, not only domestically and also abroad. Using the internet is actually one right solution in the promotion process because by marketing through the internet media, there is no longer a time limit and a more extensive marketing reach [2]. The rapid use of the internet has made developments information technology is developing faster and faster sophisticated. As for the weaknesses of the internet in distance learning, namely: 1) Requires skills in using computers; and 2) fluctuating internet networks that affect the flow of internet connections. [3]. With the development of technology This information, news sites provide convenience for the community because of the construction of the website as a means of information capable of presenting all forms more up-to-date, fast online news information present and certainly easily accessible anywhere[4].

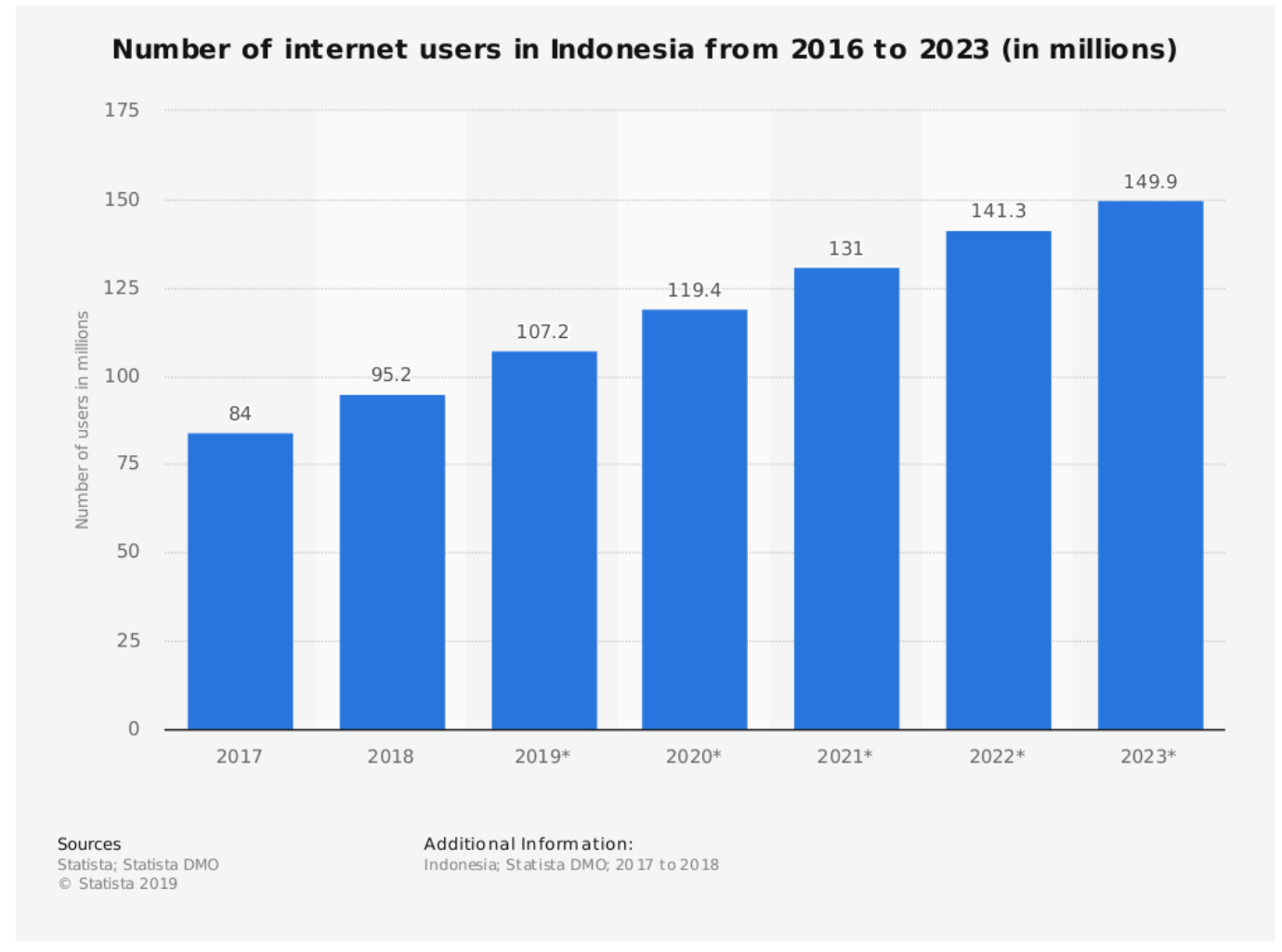

Figure 1. Internet User Projection in Indonesia 2017-2023

Source : Statista, 22 February 2019

Statista 2019 data shows that internet users in Indonesia in 2018 were 95.2 million, growing by $13.3 \%$ from 2017, which was 84 million users. In the following years, internet users in

IJCCS Vol. 14, No. 1, January 2020: $57-68$ 
Indonesia will increase with an average growth of $10.2 \%$ in the 2018-2023 period. In 2019 the number of internet users in Indonesia is projected to grow 12.6\% compared to 2018, which is 107.2 million users [5]. As technology advances today, the rate of information rotation among the public can provide access to public demand for quality, fast, and accurate information. With the principle of using ICT that is effective and efficient, optimal, attractive, and stimulates creativity, ICT becomes one of the learning media that is widely used in various fields of education because it increases the effectiveness and efficiency in the learning process [6]. iLearning+ learning methods use LMS as the role of the development of Information and Communication Technology so that it makes learning more straightforward to be done anywhere and anytime without having limitations [7]. People can study anywhere, anytime, with anyone. That is characteristic of the age of knowledge learning, which derives many models, among others, the blended learning model, which is a hybrid course combining face-toface learning (face to face learning) and computer-based learning (computer-based learning)[8]. Online learning iLearning+ is intended to make students more enthusiastic and alternative in organizing and conditioning the learning situation to be more exciting and not dull so that it can be fun and build engagement for students to attend online lectures. With the existence of distance education or blended learning shows that there is an increase in understanding of students who use knowledge based on blended learning when compared to conventional learning. The implementation of blended learning is complementary between face to face learning and e-learning learning[9][10]. Weaknesses in conducting blended learning are 1) Unequal facilities owned by students, such as computers, and access to the Internet. Blended Learning requires internet access adequate. If the network is inadequate, it will be difficult for participants to take part in independent learning online. 2) Lack of public knowledge about the use of technology[11]. The most popular source of information on the internet today is one of them is the Wordpress CMS. Wordpress CMS is currently widely used by iLearning+ because it has properties that can facilitate both installation and use. WordPress is an open system application that was built using the PHP programming language and MySQL database, both of which are part of free system software[12]. When registering on the WordPress.com site, users do not need to install or configure the website. But the deficiencies found by WordPress.com users can not make changes to the standard templates that provide. Although like that, Wordpress.com has provided features that are quite good. With Wordpress.com, the information published can be attractive so that it can have an attraction as an interactive information medium, it is because the Wordpress blog service is friendly to comment. That means it also allows users to have full control over comments, files, documents, design and display of content on the website[13]. Information distribution activities with social media have a significant influence on public satisfaction, which ultimately has an impact intention of public participation[14].

\section{METHODS}

Literature Review is a material in the form of theory that outlines a research to be used as a basis for solving various problem formulations in study that can be obtained from multiple sources, namely (books, websites, journals, etc.), which have been done before and have a harmonious correlation from several sources literature. So this study uses a literature review research analysis method, including:

A study conducted by Samsul Sahri and Heru Supriyono in 2017 discusses making a website on anime information that focuses on news related to anime titles, story summaries, characters, and knowledge of illustrations or visual media to support information using data collection methods. The results can obtain in the form of a website that contains information in 
the form of various anime that aired and spread through the internet network, which can be accessed easily[15].

Research conducted by Habib, Karar Mehdi, in 2018. Based on this research, discussing WordPress in detail and how unique integration can apply to it. The Content Management System has made it easy to develop any organization's website in a short amount of time without having any programming knowledge. Several management systems have high popularity. Some of them are WordPress, Drupal, Joomla. In all of this research focused on WordPress because it is quite well-known among other Content Management Systems (CMS)[16].

In another study by Langgeng Listiyoko, Rimadini Asri Ardi, Ali Maksum in 2018, it discusses developments that strive for real-time and flexible information. The conclusion that can obtain is the increase in article communication traffic as a result of competitive dashboard reports[17]. Research conducted by Muhamad S. Supriyadi and Heri Yanto in 2018, discussing the survey research on the effect of using E-Learning based WordPress CMS on student learning outcomes, the results are more effective in improving learning outcomes better than applying conventional learning models[18].

Muhiddin Palennari and Firdaus Daud in 2019. Based on this study, discuss developing Blended Learning strategies in Basic Biology lectures in the form of online learning media. From the results of the research, it is intended for lecturers to be able to use e-learning in talks. [19]. A study conducted by Akrivi Krouska, Christos Troussas, Maria Virvou in 2017, it discusses Content and learning management systems (CMS's/LMS's) are in abundance, providing software platforms to support web-based applications in a way that is easy to use. One major conclusion is that this platform facilitates the development of e-learning environments with social features through a user-friendly dashboard and various education-oriented services[20].

According to the research by Tika Septia, Husna, and Anna Cesaria in 2017, discussing Basic Mathematics subjects is a difficult subject for Physics students, so that it requires interactive learning to improve their knowledge. So to develop interactive media using Wordpress and to find out the effectiveness of the web as a learning medium educates ICT Literacy students. This study uses the ADDIE model. The efficiency of the interactive network can describe as completing students' ICT literacy[21].

Research that has been investigated by Andiani in 2018 that discusses the causes of failure in teaching and learning activities due to interaction and communication factors in the classroom therefore this research uses information technology as a medium of interaction and communication in learning between lecturers and students in order to run effectively and efficiently[22].

Research conducted by Saluky in 2016, discussed survey research on the development of teaching material information on learning mathematics using wordpress so $94 \%$ of the survey results stated that it was very good so that it was feasible to use because it was considered effective in obtaining information about mathematics education [23].

Research conducted by Fajar Mahendra in 2016, it discusses the main problems faced by SLB N Salatiga, namely that people have difficulty in getting information because the information will be obtained when they come to school and distribute pamphlets. Then made a web-based information system using Wordpress for easy access by anyone[24].

From 10 previous research references, a research analysis was conducted and a conclusion was drawn that there had not been any innovation for web-based interactive learning media online. So as to create a construction in the form of iLearning+ model consisting of 9 (nine) points and connected to each other, more fully explained in Figure 2 below.

IJCCS Vol. 14, No. 1, January 2020: $57-68$ 


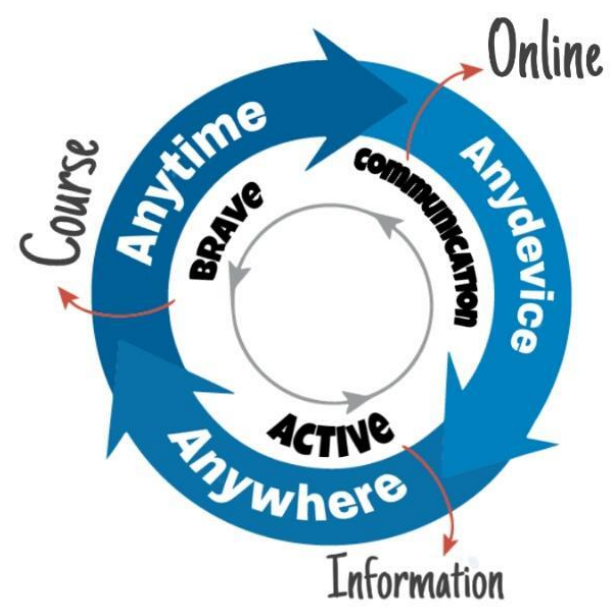

Figure 2. iLearning+ Model

(Source: https://ilp.alphabetincubator.id/)

Figure 2 is a model of learning iLearning+, namely distance education. Therefore by using the web based system to get information about lectures or material can be accessed anytime, anywhere, and can access various devices that are connected to the internet. Make learning on iLearning+ run effectively and efficiently and the delivery of information can be widely distributed without having to do face-to-face.

\section{RESULTS AND DISCUSSION}

The utilization of ICT in learning is expected to make learning methods and processes more varied to produce optimal behavioral changes for students. Currently, the iLearning+ learning method that relies on technological sophistication as a medium of learning. Knowledge and information can be done online through the iLearning+ website, through the ilp.alphabetincubator.id domain for students and lecturers so that teaching and learning activities can run, data distribution can be done effectively and efficiently anywhere and anytime without having to come to campus and meet directly with the lecturer. The iLearning+ website is designed flexibly by using Wordpress.com and materialist themes so that the iLearning+ site has an excellent appeal and for managing the information in it is done efficiently so that information can be widely publicity. As an embodiment of the research system above, a web-based information system was created as information and interactive media on iLearning+.

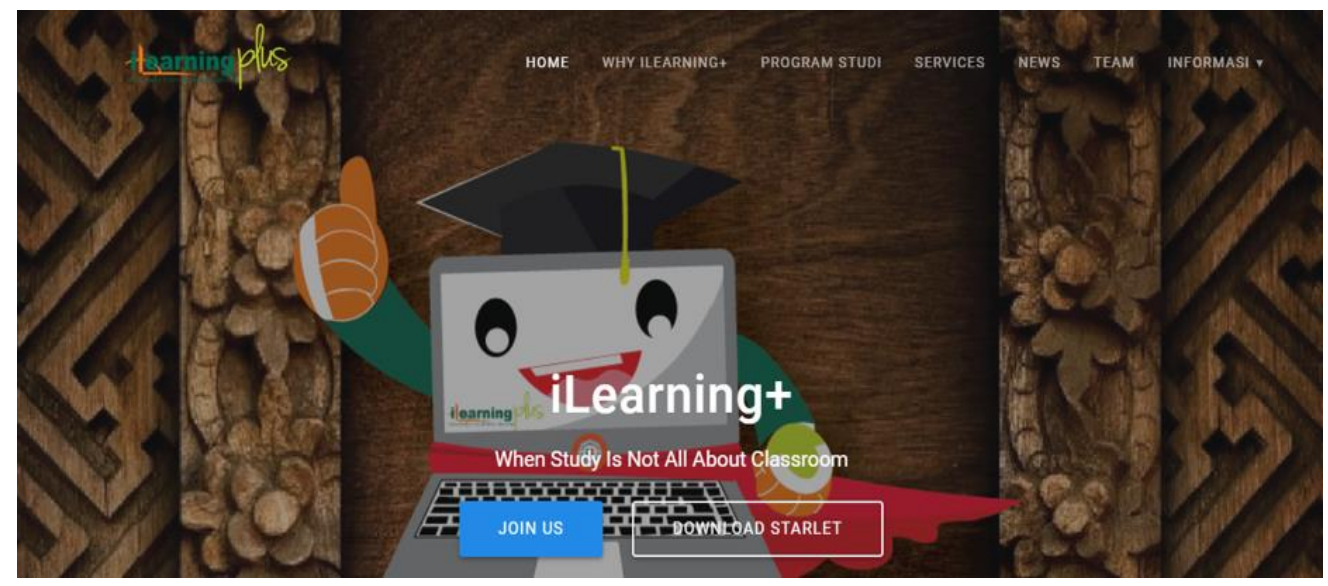

Figure 3. iLearning+ Web Start Page

(Source: https://ilp.alphabetincubator.id/) 
Figure 3 is the starting page on the iLearning+ website in this view using the slide bar, which is a picture that has to provide can be set to move according to a predetermined time and has the iLearning+ logo to make it more attractive on the slide bar. This display has six menus that will go to the page below and has provided two buttons to join and download starlets as reference information about iLearning+.

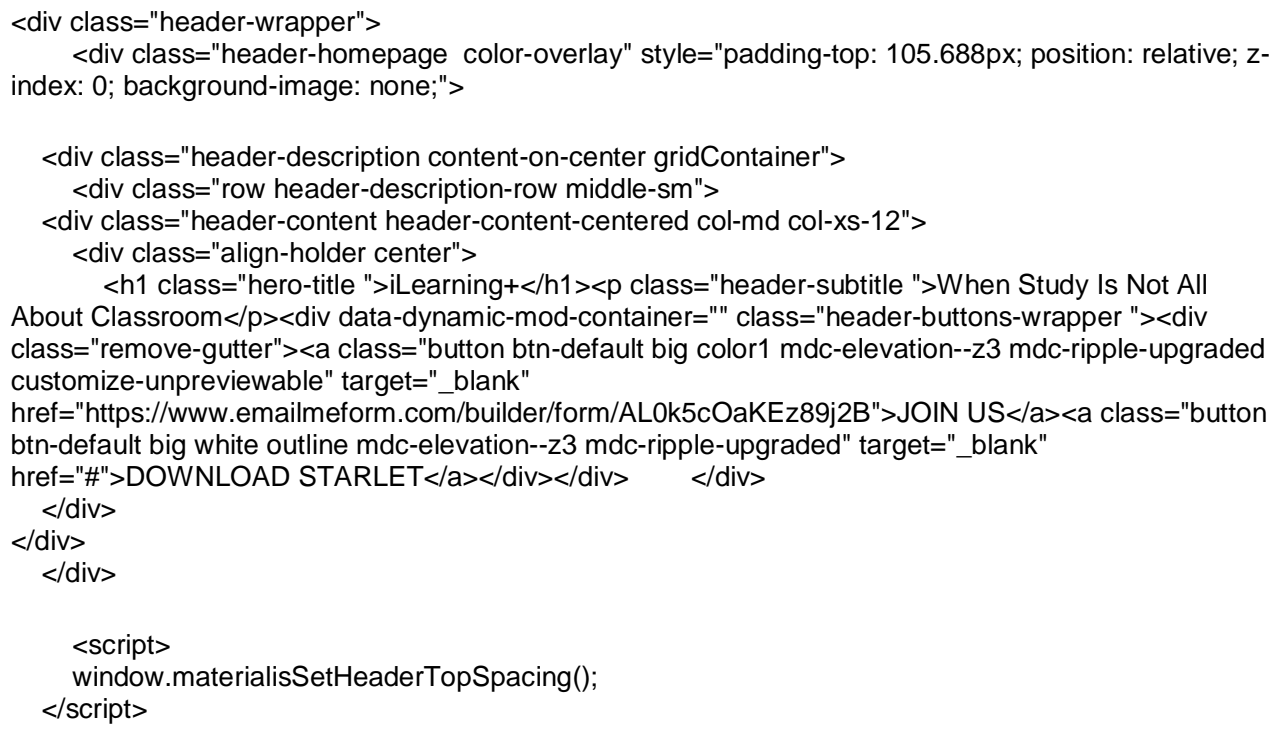

The program list above is coding from the start page of the iLearning+ web, in this case, using the HTML, CSS, and Javascript components.

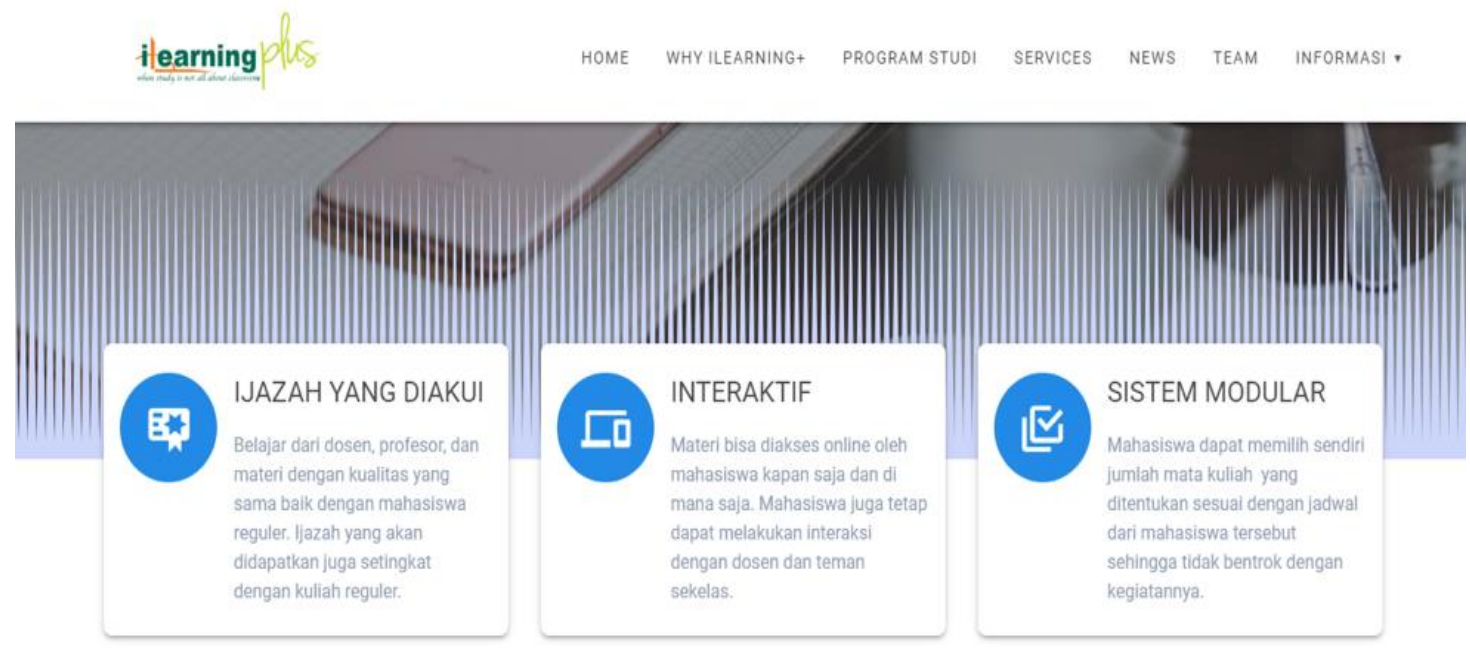

Figure 4. Webpage 3 iLearning + advantages

(Source: https://ilp.alphabetincubator.id/)

Figure 4 above explains the web iLearning+ lists three advantages when choosing to follow the lectures on iLearning+. In this case, using the Manage Page Section, namely, Overlap Table on the theme, customize Wordpress.com materialist. 


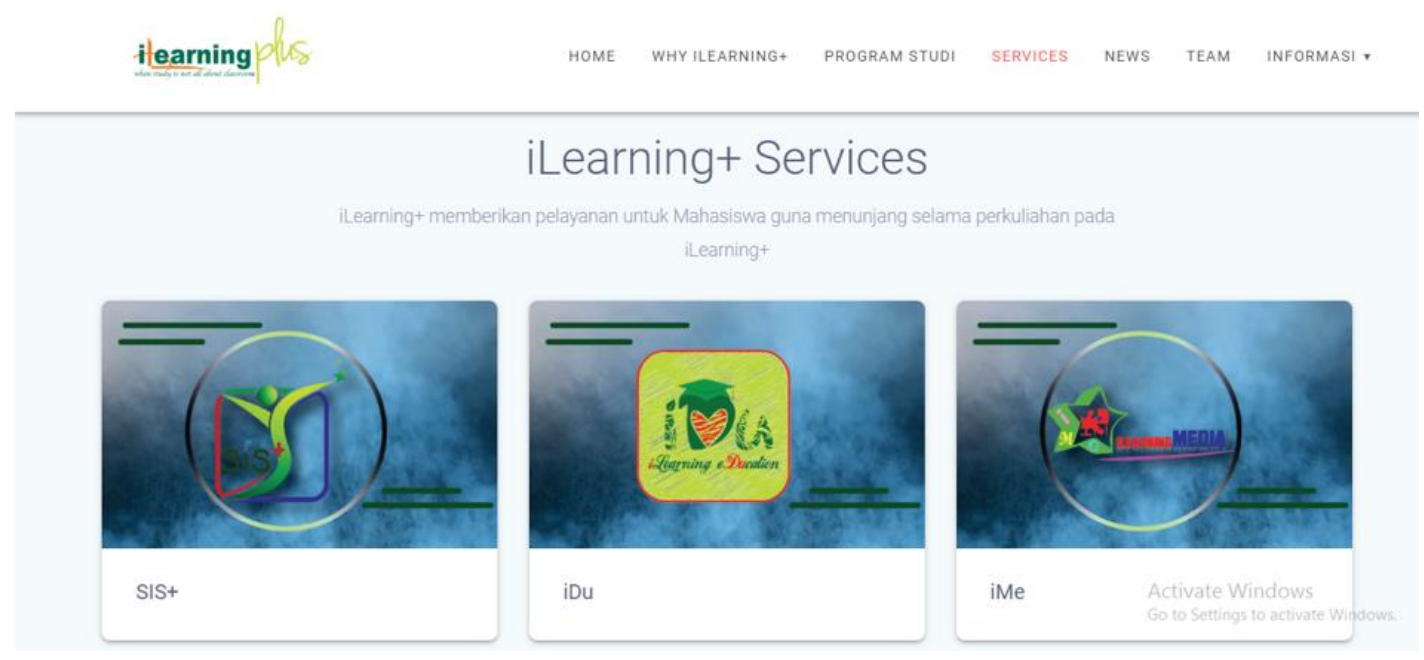

Figure 5. iLearning + services webpage

(Source: https://ilp.alphabetincubator.id/)

Figure 5 above is a web display of iLearning+ regarding services that have been provided by iLearning+ such as SIS+, iDu, iMe, etc. This feature uses features from the features provided by the Wordpress.com materialist theme.

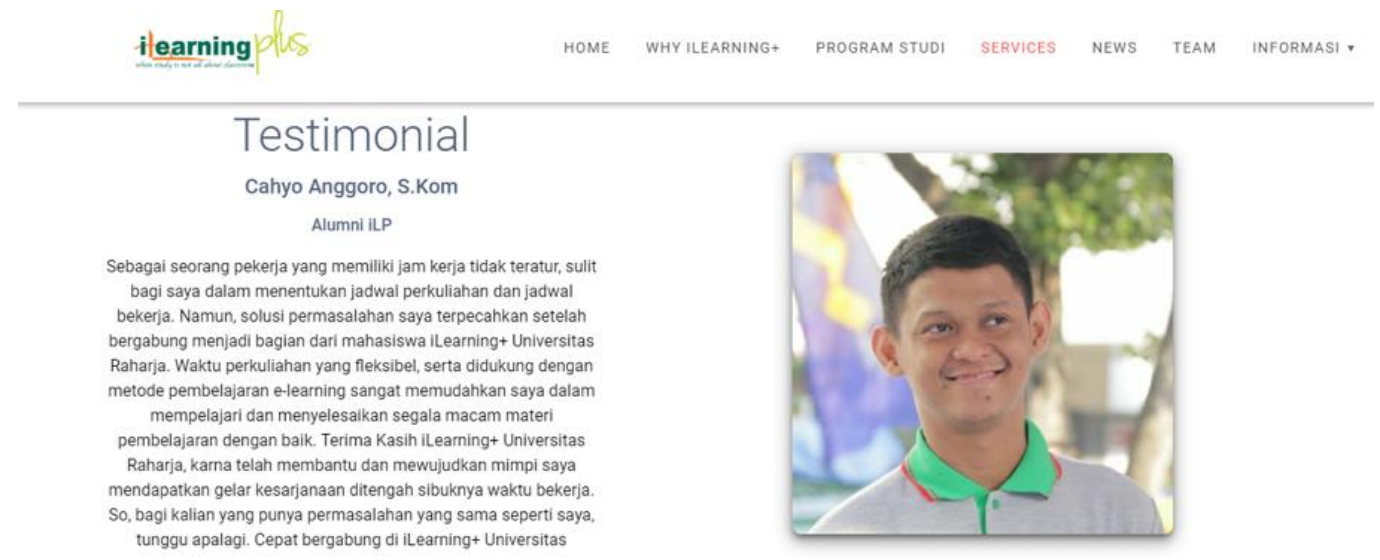

Figure 6. iLearning+ Testimonials Webpage

(Source: https://ilp.alphabetincubator.id/)

The 6 picture is a display of testimonials from iLearning+ so that it will create an interest in being able to attend iLearning+ lectures. In this view, the affidavits feature provided by the theme used is a materialist. 


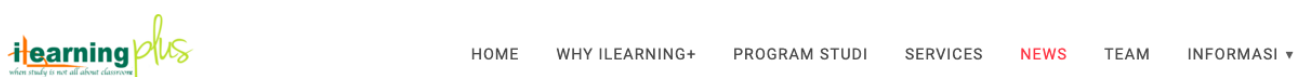

Learning+ akan memberikan informasi - informasi yang terkait dengan iLearning+ seperti

Pelatihan, Seminar maupun info seputar Kampus

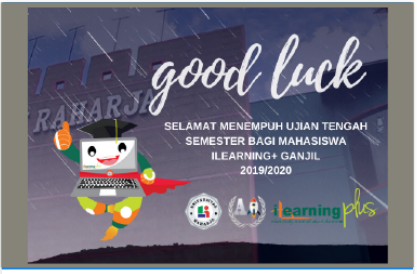

ILearning+

Jadwal UTS iLearning+ Ganjil 2019/2020

SAHABAT BINBU Sahabat - sahabat Binbu sedang menjalani UTS nih $\rightarrow$ Ujian Tengah

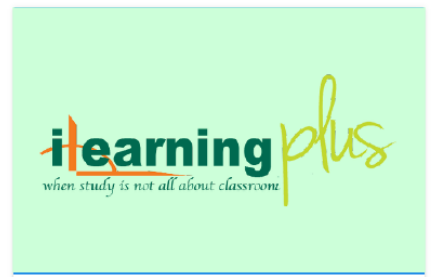

ILearning+

Filosofi Maskot iLearning+ H A L L O SO B A T!!! Sebelum menjelaskan tentang Filosofi dari[...]

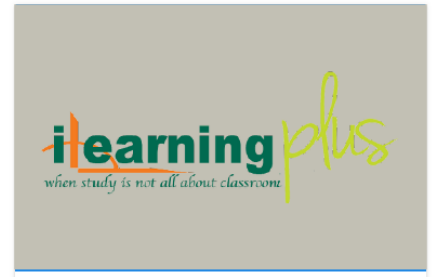

ILearning+

Kuliah Online Terbaik di

Tangerang

Sebagai Kampus IT Terbaik di Tangerang yang sudah bergerak lama, Universitas

Figure 7. iLearning + Latest Information Webpage

(Source: https://ilp.alphabetincubator.id/)

Figure 7 displays the display of the latest information on iLearning+ so that this display makes the iLearning+ website more up to date and always active in providing information.

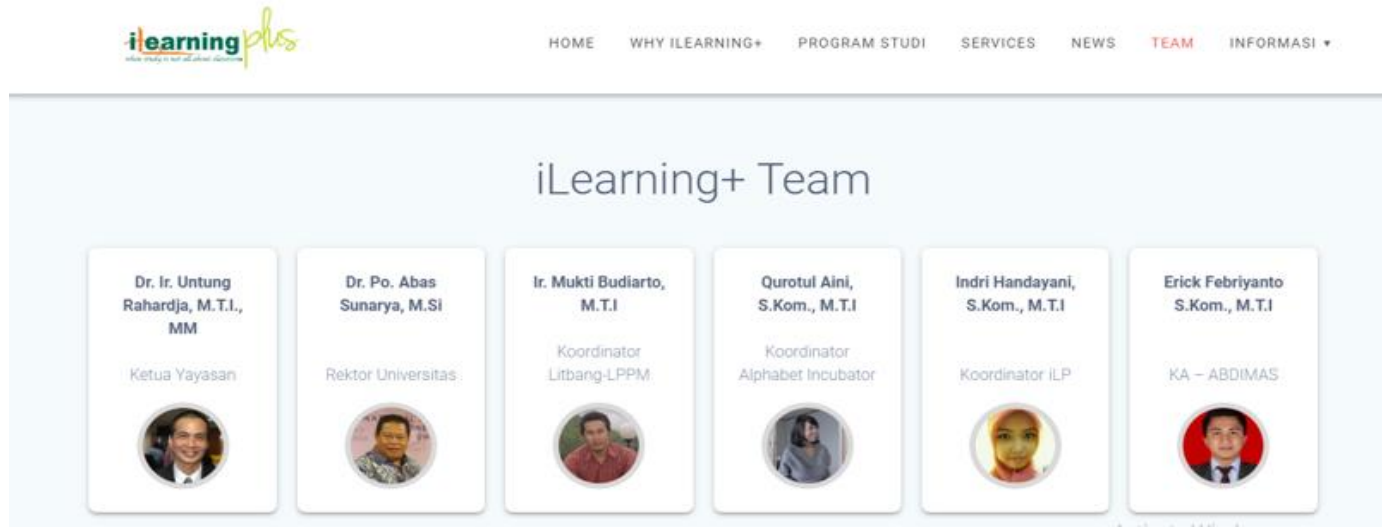

Figure 8. iLearning+ Members Webpage (Source: https://ilp.alphabetincubator.id/)

The picture above is a display for iLearning+, which already has a membership structure on iLearning+, so that makes the iLearning+ web look attractive and attractive because it already has a structured membership structure.

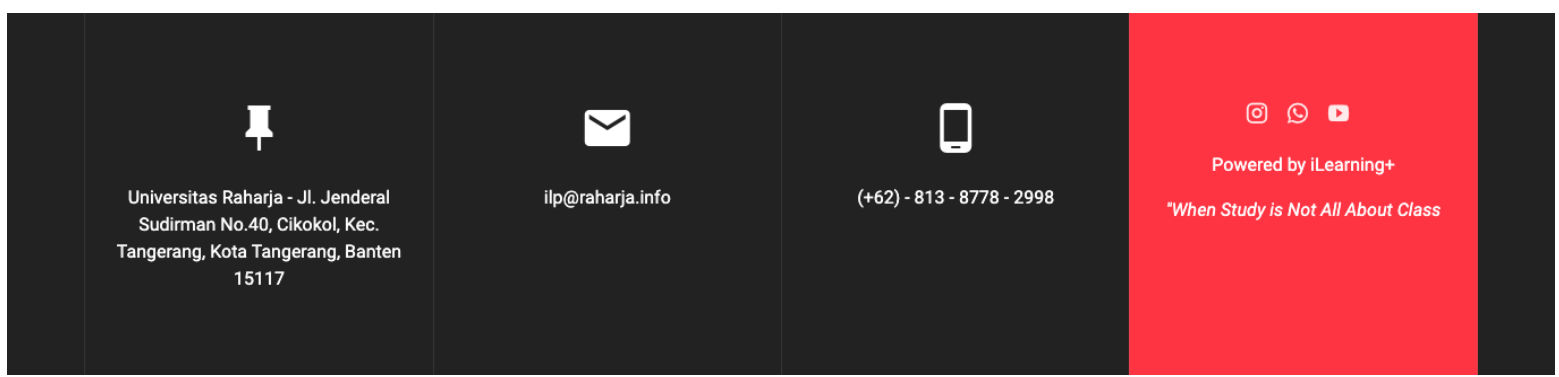

Figure 9. iLearning + Contact Information Webpage

(Source: https://ilp.alphabetincubator.id/) 
Figure 9 displays the display on the iLearning+ website regarding contact information owned by iLearning+ so that if anyone wants to ask further about iLearning+ can contact the contact provided. Display contact information can be so interesting by using the Contact feature that has been provided by the Wordpress.com materialist theme.

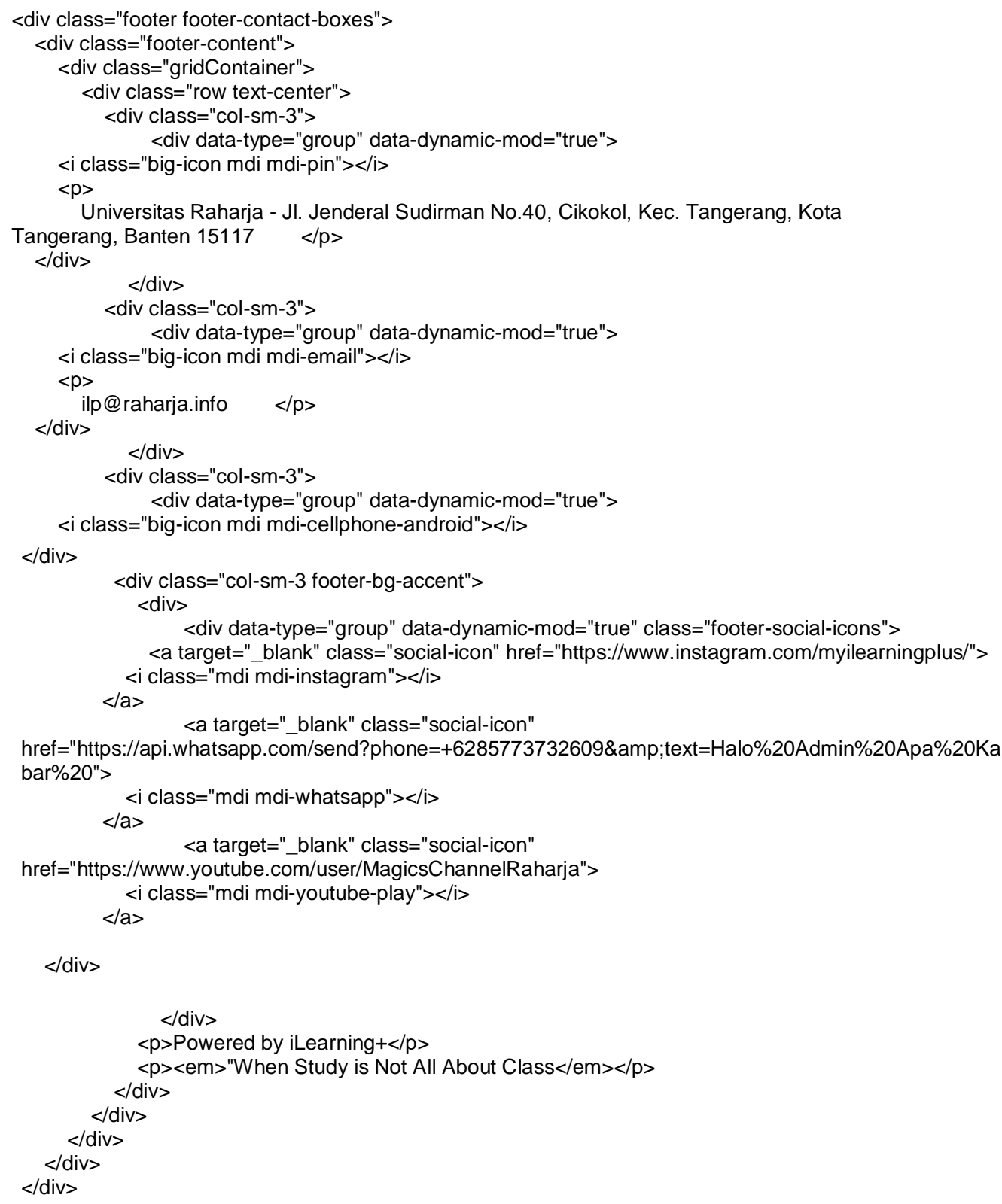

The following is the writing of the Word Coded Footer, where this uses the theme provided, but editing the red part has to be done with HTML, CSS, and Javascript coding, which is open from the Wordpress CPanel. 


\section{CONCLUSIONS}

Based on the discussion above that has discussed the Role of the Development of Information and Communication Technology in iLearning+ lectures, it proves that the Development of Information and Communication Technology holds very tightly to an essential role in the iLearning+ lecture process. This utilization can be in the form of system development in lectures and information. iLearning+ has shown that learning and getting interactive reports can be done anywhere and anytime. iLearning+ as an interactive information media and the appearance of WordPress as support for iLearning+ learning activities and the distribution of information widely. All forms of lecture activities carried out with Wordpress online through the website ilp.alphabetincubator.id for students and lecturers so that teaching and learning process activities and information distribution can run without being bound by place and time.

\section{REFERENCES}

[1] U. Rahardja, A. Moeins, and N. Lutfiani, "Leadership, competency, working motivation and performance of high private education lecturer with institution accreditation B: Area kopertis IV Banten province,” Man India, vol. 97, no. 24, pp. 179-192, 2017.

[2] D. A. Praditya and B. Soepeno, "Penggunaan Aplikasi CMS Wordpress Untuk Merancang Website Sebagai Media Promosi pada Maroon Wedding Malang," Akuntansi, Ekon. dan Manaj. Bisnis, vol. 2, no. 1, pp. 63-69, 2014 [Online]. Available: https://jurnal.polibatam.ac.id/index.php/JAEMB/article/view/135. [Accessed: 02-Okt2019]

[3] M. M. E. I. Bali, "Implementasi Media Pembelajaran Berbasis Teknologi Informasi dan Komunikasi dalam Distance Learning,” Tarbiyatuna, vol. 3, no. 1, pp. 28-38, 2019.

[4] A. B. Warsito, I. Handayani, and Y. Dewi, "Sistem Berita Online Berbasis Web Pada Perguruan Tinggi Raharja,” pp. 6-7, 2016.

[5] “• Number of internet users in Indonesia 2023 | Statista." [Online]. Available: https://www.statista.com/statistics/254456/number-of-internet-users-in-indonesia/. [Accessed: 02-Nov-2019].

[6] "Pemanfaatan ICT Sebagai Media Pembelajaran dan Informasi Pada UIN Alauddin Makassar | Rahim | Sulesana: Jurnal Wawasan Keislaman.” [Online]. Available: http://journal.uin-alauddin.ac.id/index.php/sls/article/view/1408/1365. [Accessed: 16Dec-2019].

[7] I. Handayani, E. Febriyanto, and C. Y. Kristanti, "Komunikasi Dalam Pembelajaran Ilearning Plus Di," vol. 16, no. 2, 2019 [Online]. Available: https://ejournal.undiksha.ac.id/index.php/JPTK/article/view/17859/11366. [Accessed: 10-Okt-2019]

[8] R. Kuntarto, Eko dan Asyhar, "Pengembangan Model Pembelajaran Blended Learning pada Aspek Learning Design dengan Platform Media Sosial Online sebagai Pendukung Perkuliahan Mahasiswa," pp. 1-26, 2016. 
[9] N. Aeni, T. Prihatin, and Y. Utanto, "Pengembangan Model Blended Learning Berbasis Masalah pada Mata Pelajaran Sistem Komputer," Innov. J. Curric. Educ. Technol., vol. 6, no. 2, pp. 27-38, 2017.

[10] F.- Inggriyani, A. R. Hamdani, and T. Dahlan, "Minat Belajar Mahasiswa dengan Menggunakan Blended Learning melalui Google Classroom pada Pembelajaran Konsep Dasar Bahasa Indonesia SD," PEMBELAJAR J. Ilmu Pendidikan, Keguruan, dan Pembelajaran, vol. 3, no. 1, p. 28, 2019.

[11] W. Prayitno, "Implementasi Blended Learning dalam Pembelajaran pada Pendidikan Dasar dan Menengah," Artik. LPMP D.I. Yogyakarta, pp. 1-14, 2015.

[12] U. Rahardja, I. Handayani, and A. A. Ningrum, "Pemanfaatan Sistem iMe Berbasis WordPress sebagai Official Site RCEP pada Perguruan Tinggi," Creat. Inf. Technol. J., vol. 4, no. 3, p. 207, 2018 [Online]. Available: http://citec.amikom.ac.id/main/index.php/citec/article/view/111. [Accessed: 10-Okt2019]

[13] "WordPress As A CMS." [Online]. Available: https://www.theseus.fi/handle/10024/171574. [Accessed: 18-Dec-2019].

[14] T. Hariguna, U. Rahardja, and Q. Aini, "ScienceDirect Effect of social media activities to determinants public participate intention of e-government," vol. 00, pp. 1-8, 2019.

[15] E. Rahmawati and Rahmat, "Perancangan Sistem Informasi Akademik Berbasis Web," Teh. Komput., p. 169, 2018.

[16] K. M. Habib, "Wordpress-A convenient content-management system (CMS) Thesis WordPress-A convenient content-management system (CMS) Abstract Author Title Number of Pages Date," 2018.

[17] L. Listiyoko, R. A. Ardi, and A. Maksum, "Implementasi Live Dashboard Dalam Pengembangan Business Intelligence Pada E-Learning STMIK Muhammadiyah Banten," Semnasteknomedia Online, vol. 6, no. 1, pp. 2-10, 2018.

[18] M. S. Supriyadi and H. Yanto, "Feasibility Implementation E-Learning Based on CMS Wordpress for Professional Ethics," KnE Soc. Sci., vol. 3, no. 10, p. 719, 2018.

[19] I. O. Dan, M. Kerja, T. Kinerja, and T. Itje, "Indonesian Educational Studies ( Ijes )," vol. 21, no. 1, pp. 86-98, 2018.

[20] A. Krouska, C. Troussas and M. Virvou, "Comparing LMS and CMS platforms supporting social e-learning in higher education," 2017 8th International Conference on Information, Intelligence, Systems \& Applications (IISA), Larnaca, 2017, pp. 1-6.

[21] T. Septia, Husna, and A. Cesaria, "Interactive basic mathematics web using Wordpress," J. Phys. Conf. Ser., vol. 943, no. 1, 2018.

[22] "Interaksi Dan Komunikasi Berbasis Teknologi Informasi Dan Komunikasi Dalam Pendidikan | Andiani | Jutisi: Jurnal Ilmiah Teknik Informatika dan Sistem Informasi." [Online]. Available: http://ojs.stmikbanjarbaru.ac.id/index.php/jutisi/article/view/232/218. [Accessed: 16-Dec-2019]. 
[23] "PENGEMBANGAN BAHAN AJAR MATEMATIKA BERBASIS WEB DENGAN MENGGUNAKAN WORDPRESS | Saluky | Eduma : Mathematics Education Learning and Teaching." [Online]. Available: http://syekhnurjati.ac.id/jurnal/index.php/eduma/article/view/685/567. [Accessed: 16Dec-2019].

[24] F. Mahendra, "Perancangan Website Sekolah Slb N Salatiga Dengan,” 2016. 